\title{
Expression of the crustacean hyperglycaemic hormones and the gonad-inhibiting hormone during the reproductive cycle of the female American lobster Homarus americanus
}

\author{
D P V de Kleijn, K P C Janssen, S L Waddy ${ }^{1}$, R Hegeman, \\ W Y Lai ${ }^{1}$, G J M Martens and F Van Herp \\ Department of Animal Physiology, Faculty of Science, University of Nijmegen, Toernooiveld, 6525 ED Nijmegen, The Netherlands and ${ }^{1}$ Invertebrate Fisheries \\ Section, Biological Station, Department of Fisheries and Oceans, St Andrews, New Brunswick, Canada E0G 2X0 \\ (Requests for offprints should be addressed to F Van Herp)
}

\begin{abstract}
Crustacean reproduction is regulated by a complex chain of hormonal interactions in which the crustacean hyperglycaemic hormones A and $\mathrm{B}(\mathrm{CHH}-\mathrm{A}$ and $\mathrm{CHH}-\mathrm{B})$ and the gonad-inhibiting hormone $(\mathrm{GIH})$ play a primary role. These neurohormones are produced in the same neuroendocrine cells of the X-organ sinus gland complex, situated in the eyestalks of the American lobster, Homarus americanus. In order to obtain more information on the synthesis, storage, release and function of these three neuropeptides during the reproductive cycle, we studied the levels of their mRNAs in the X-organ, their peptide storage in the sinus gland and their concentration in the haemolymph at different stages of the female reproductive cycle. A high CHH-A mRNA level was found only in the previtellogenic stage, while elevated mRNA levels were determined for $\mathrm{CHH}-\mathrm{B}$ in the mature as well as the previtellogenic stage. High $\mathrm{CHH}$ storage levels in the
\end{abstract}

sinus gland were found during previtellogenesis. The total amount of $\mathrm{CHH}$ (CHH-A plus -B) in the haemolymph was significantly higher during maturation. A low level of GIH mRNA in the X-organ and a low amount of the GIH I isoform in the sinus gland were found only in the immature stage. In contrast, GIH haemolymph levels were high during the immature and previtellogenic stages. We conclude that $\mathrm{CHH}-\mathrm{A}$ and $-\mathrm{B}$ are involved in triggering the onset of vitellogenesis and that $\mathrm{CHH}-\mathrm{B}$ in particular is responsible for stimulating oocyte maturation before spawning, while GIH prevents the start of vitellogenesis in the ovary. Moreover, our results show that the balance between the haemolymph levels of the CHHs and GIH may tune the synchronization of reproduction and molting during the biannual reproductive cycle of the American lobster.

Journal of Endocrinology (1998) 156, 291-298

\section{Introduction}

As reflected by their names, the crustacean hyperglycaemic hormones (CHHs) are primarily involved in the regulation of carbohydrate metabolism while the gonadinhibiting hormone $(\mathrm{GIH})$, also called vitellogenesisinhibiting hormone (VIH), is important for the inhibition of vitellogenesis. Together with the molt-inhibiting hormone (MIH), these neurohormones belong to the CHH/ MIH/VIH neuropeptide family (Keller 1992). They are all produced in the neuroendocrine cells of the medulla terminalis X-organ, localized in the crustacean eyestalks, and are transported to the clustered axon endings of the cells that form the aneurohemal organ, the sinus gland. Detailed in situ hybridization and immunocytochemical studies revealed a frequent colocalization of the two neurohormones in the eyestalks of lobster (Kallen \& Meusy 1989, De Kleijn et al. 1992).
HPLC analysis of sinus gland extracts showed that $\mathrm{CHH}$ and GIH are present in different isoforms. For example, in lobster, $\mathrm{CHH}$ is eluted as two immunoreactive groups (CHH-A and $\mathrm{CHH}-\mathrm{B})$ and $\mathrm{GIH}$ as one immunoreactive group (Tensen et al. 1991, Meusy \& Soyez 1991). Each of the three groups consists of two isoforms with identical amino acid sequences and molecular masses (Tensen et al. 1991, Soyez et al. 1991). It was recently established that the presence of a D-phenylalanine residue in one of the $\mathrm{CHH}$ isoforms of both $\mathrm{CHH}$-immunoreactive groups is responsible for the difference in HPLC elution time (Soyez et al. 1994). The $\mathrm{CHH}$ isoforms are therefore characterized as $\left[\mathrm{L}-\mathrm{Phe}^{3}\right]-$ and $\left[\mathrm{D}-\mathrm{Phe}^{3}\right]-\mathrm{CHH}-\mathrm{A}$ and $\left[\mathrm{L}-\mathrm{Phe}^{3}\right]-$ and [D-Phe $\left.{ }^{3}\right]-\mathrm{CHH}-\mathrm{B}$.

The function of GIH in female lobsters may be concerned with the inhibition of the onset of vitellogenesis, as shown by Soyez et al. (1987) using a heterologous bioassay. However, since GIH is also present in male lobsters 
(De Kleijn et al. 1992), it must also have another role. After determination of the amino acid sequence of preproGIH and its alignment with the sequence of crab preproMIH, we found that not only do the mature hormones have a high degree of amino acid identity but the primary structures of their preprohormones are also nearly identical (De Kleijn et al. 1994). Therefore we suggested that GIH may be an important modulator of synthesis or release of hormones involved in molting as well as the reproductive process (De Kleijn et al. 1994).

The multifunctionality of $\mathrm{CHH}$ has already been demonstrated. While all $\mathrm{CHH}$ isoforms have a hyperglycaemic effect, CHH-B can also stimulate oocyte growth (Tensen et al. 1989) and CHH-A may display molt-inhibiting activity (Chang et al. 1991). Moreover, the effects of eyestalk ablation and implantation of thoracic/abdominal ganglia indicated the presence of a vitellogenic-stimulating hormone (Otsu 1963, Gomez \& Nayar 1965, Aiken \& Waddy 1980). These results, in combination with recent studies showing that $\mathrm{CHH}-\mathrm{A}$ and $-\mathrm{B} \mathrm{mRNAs}$ are present in parts of the nervous system other than the optic ganglia, indicate that $\mathrm{CHH}$ may have an additional role in the control of reproduction and molting (De Kleijn et al. 1995).

Studies on the (neuro)endocrine regulation of crustacean reproduction and molting in general have revealed that both processes are controlled by the interaction of several neuropeptides, juvenoids and steroids and that their control is more complex than believed previously (see reviews by Chang (1997), Charmantier et al. (1997) and Van Herp \& Soyez (1997)). The existence of several groups and isoforms of the $\mathrm{CHH}$ and $\mathrm{GIH}$ neuropeptides in lobster, in combination with the fact that the gonadinhibiting activity of lobster GIH has only been tested in a heterologous bioassay with prawns and that lobsters seem to use $\mathrm{CHH}$ and/or GIH for inhibition of their molting process, suggests that further studies on the physiological role of these neuropeptides are required. We therefore investigated the synthesis, storage and release of $\mathrm{CHH}-\mathrm{A}$ and $-\mathrm{B}$ and $\mathrm{GIH}$ during different stages of the female reproductive cycle in the lobster Homarus americanus.

\section{Materials and Methods}

\section{Animals}

Specimens of the American lobster Homarus americanus were obtained commercially at Miminegash, Prince Edward Island, Canada. Experimental female animals were selected in September 1993 based on their molting stage (stages C1-C4) and their carapace length (81$85 \mathrm{~mm})$. As the lobster has a biannual reproductive cycle, these females would be mature and would spawn normally in the summer of 1995. However, artificial induction of spawning by the method of Waddy \& Aiken (1992) permitted the different reproductive stages to be obtained at an earlier period. The reproductive condition of each female was confirmed by examining the pleopodal cement glands in early spring 1994, and all animals selected were kept in vertically stacked tanks with plexiglass front panels so that spawning could be observed without disturbing the animals.

In March 1994, a first group of animals was put into the artificially changed environmental conditions $\left(12{ }^{\circ} \mathrm{C}, 8 \mathrm{~h}\right.$ light: $16 \mathrm{~h}$ darkness) to induce spawning at the beginning of April 1994. These animals were used to study the different parameters during the reproductive stages after spawning. At the beginning of April 1994, a second group was put into the same changed environmental conditions in order to study the different parameters during maturation and the period before spawning.

The reproductive stage of each animal was determined by the method of Aiken \& Waddy (1980), in which a combination of weight, colour and developmental stage of the ovary is used as the criterion.

\section{Isolation of $R N A$}

Total RNA was isolated by the method of Chomczynski \& Sacchi (1987), using acid guanidinium thiocyanatephenol-chloroform extraction. Medulla terminalis tissue from the two eyestalks of each animal was pooled and homogenized in an all-glass homogenizer containing $500 \mu \mathrm{l}$ guanidinium thiocyanate solution (4 M guanidinium thiocyanate; $25 \mathrm{mM}$ sodium citrate, $\mathrm{pH} 7 \cdot 0 ; 5 \%$ sarcosyl; $0 \cdot 1$ M 2-mercaptoethanol). Sequentially, $50 \mu \mathrm{l}$ $2 \mathrm{M}$ sodium acetate $(\mathrm{pH} 4 \cdot 1), 500 \mu \mathrm{l}$ water-saturated phenol and $100 \mu \mathrm{l}$ chloroform-isoamyl acohol (49:1) were added, the sample was mixed vigorously and the RNA was recovered after ethanol precipitation. RNA preparations were used in an RNase protection assay.

\section{Labelling and purification of $R N A$ probes}

RNA probes were synthesized as run-off transcripts from 200 ng linearized plasmid DNA of pBluescript $\mathrm{KS}^{+}$plus insert. Labelling was performed in a final volume of $10 \mu \mathrm{l}$ containing $50 \mu \mathrm{Ci}\left[{ }^{32} \mathrm{P}\right] \mathrm{UTP}, 15$ units T3/T7 RNA polymerase in transcription buffer (Promega), 17.5 U RNasin (Promega) and $1 \mathrm{mM}$ ribo(r)ATP, rCTP and rGTP. After an incubation of $30 \mathrm{~min}$ at $37^{\circ} \mathrm{C}$, the probe was separated from the template by electrophoresis on a $4 \%$ polyacrylamide gel. RNA was eluted from the gel in $500 \mu \mathrm{l} 2.5 \mathrm{M}$ ammonium acetate, $\mathrm{pH} 4 \cdot 6$, over $2 \mathrm{~h}$ at $55^{\circ} \mathrm{C}$ and then precipitated with ethanol using $20 \mu \mathrm{g}$ tRNA as carrier.

Quantification of CHH-A, CHH-B and GIH $m$ RNA levels in the eyestalk by RNase protection assay

For CHH-A, CHH-B and GIH, cDNA fragments (CHH-A, nucleotides 183-395; CHH-B, nucleotides 
675-865 (De Kleijn et al. 1995); GIH, nucleotides 527850 (De Kleijn et al. 1994)) were cloned into pBluescript and used as templates for specific cRNA probes. After synthesis and purification, each cRNA probe was dissolved in the protection-assay hybridization mix $(80 \%$ formamide, $400 \mathrm{mM} \mathrm{NaCl}, 40 \mathrm{mM}$ 1,4-piperazinediethanesulphonic acid, $\mathrm{pH}$ 6.4, $1 \mathrm{mM}$ EDTA). Separately, total RNA samples obtained from the collected eyestalks were dissolved in $23 \mu \mathrm{l}$ protection-assay hybridization mix. After addition of $2 \mu \mathrm{l}$ RNA probe and incubation for $10 \mathrm{~min}$ at $80{ }^{\circ} \mathrm{C}$, hybridization was performed for $16 \mathrm{~h}$ at $55^{\circ} \mathrm{C}$. Next, $300 \mu \mathrm{l}$ RNase digestion buffer $(10 \mathrm{mM}$ Tris- $\mathrm{HCl}$, $\mathrm{pH} 7 \cdot 5,5 \mathrm{mM}$ EDTA, pH 8.0, $300 \mathrm{mM} \mathrm{NaCl}, 25 \mu \mathrm{g}$ RNase $\mathrm{A} / \mathrm{ml}, 500 \mathrm{U}$ RNase $\mathrm{T} 1 / \mathrm{ml}$ ) was added, the mixture was incubated for $30 \mathrm{~min}$ at $37^{\circ} \mathrm{C}, 8 \mu \mathrm{g} / \mathrm{ml}$ proteinase $\mathrm{K}$ and $0 \cdot 1 \%$ SDS were added, and the incubation was continued for another $30 \mathrm{~min}$ at $37^{\circ} \mathrm{C}$. Samples were phenol-extracted, ethanol-precipitated, dissolved in $5 \mu \mathrm{l}$ formamide loading mix $(80 \%$ formamide, $1 \mathrm{mM}$ EDTA, pH 8.0, $1 \mathrm{mg} / \mathrm{ml}$ xylene cyanol, $1 \mathrm{mg} / \mathrm{ml}$ bromophenol blue) and loaded on to a $4 \%$ polyacrylamide gel. After electrophoresis, the gel was fixed by drying and exposed to an X-ray film using an intensifying screen at $-70{ }^{\circ} \mathrm{C}$.

The radioactivity present in the protected band was estimated by scintillation counting of the corresponding gel fragment. The amount of CHH mRNA was calculated from a dilution series of sense cRNA.

\section{MicroHPLC analysis}

Both sinus glands of one animal were dissected and collected in a glass-glass homogenizer cooled with dry ice, immediately homogenized in $350 \mu \mathrm{l} 0 \cdot 1 \mathrm{M} \mathrm{HCl}$, heated at $80{ }^{\circ} \mathrm{C}$ for $5 \mathrm{~min}$ and then freeze-dried. Before chromatography, the dried samples were dissolved in $45 \mu \mathrm{l}$ solvent $\mathrm{A}$ $(0 \cdot 1 \%$ trifluoroacetate in water) and centrifuged at $12000 \boldsymbol{g}$ for $30 \mathrm{~min}$. The supernatant was then injected on to a microHPLC system (SMART, Pharmacia LKB, Uppsala, Sweden) using a reversed-phase column (type $\mu$ RPC $\mathrm{C}_{2}$ / $\mathrm{C}_{18} ; 2 \cdot 1 \times 100 \mathrm{~mm}$; particle size $3 \mu \mathrm{m}$; gel volume $350 \mu \mathrm{l}$ ). The peptides were eluted with a gradient using solvent $\mathrm{A}$ and solvent $\mathrm{B}(80 \%$ acetonitrile $/ 20 \%$ water $/ 0 \cdot 1 \%$ trifluoroacetate): $100 \%$ solvent A, $5 \mathrm{~min} ; 0 \% \mathrm{~B}$ to $35 \% \mathrm{~B}, 5 \mathrm{~min}$; $35 \% \mathrm{~B}$ to $65 \% \mathrm{~B}, 30 \mathrm{~min} ; 65 \% \mathrm{~B}$ to $100 \% \mathrm{~B}, 15 \mathrm{~min}$. The flow rate was $200 \mu \mathrm{l} / \mathrm{min}$. UV detection was performed at $214 \mathrm{~nm}$ using a UV-MII $\mu$ Peak Monitor (Pharmacia LKB).

To calculate the relative amounts of the different $\mathrm{CHH}$ and GIH isoforms in both sinus glands of individual lobsters, the chromatographic data were evaluated with the SMART Manager 1.31 software enabling comparison and integration by area and height of the peaks corresponding to the elution time of the respective $\mathrm{CHH}$ and GIH isoforms. Details on the identification of the peptides and their elution pattern in a microHPLC analysis, as used in this study, are described by Van Herp (1992) and Soyez et al. (1994).

Determination of $\mathrm{CHH}$ and GIH haemolymph levels by a double-sandwich ELISA

Haemolymph sampling Haemolymph samples were taken from the tail with a $1 \mathrm{ml}$ syringe. The haemolymph was divided into five fractions of $200 \mu$, each diluted 1:1 with haemolymph buffer (PBS (10 mM sodium phosphate, $\mathrm{pH} 7 \cdot 2,0 \cdot 1 \% \mathrm{KCl}, 0 \cdot 8 \% \mathrm{NaCl}), 0 \cdot 03 \%$ EDTA, $\mathrm{pH}$ $8 \cdot 0,2 \% \mathrm{BSA}$ and $0 \cdot 02 \%$ sodium azide). After centrifugation $(1 \mathrm{~min}$ at $12000 \mathrm{~g})$, the supernatants were stored at $-20{ }^{\circ} \mathrm{C}$.

ELISA Based on earlier findings (Klein 1989), a doublesandwich ELISA was developed to measure $\mathrm{CHH}$ and GIH haemolymph levels during the reproductive cycle. For this purpose three antisera were used: a polyclonal rabbit anti-Astacus leptodactylus $\mathrm{CHH}$ serum (GorgelsKallen \& Van Herp 1981), a polyclonal guinea pig antiHomarus americanus $\mathrm{CHH}$ serum against HPLC-purified CHH (Meusy \& Soyez 1991) and a polyclonal rabbit antiHomarus americanus GIH serum against HPLC-purified GIH (gift from Dr Soyez, Ecole Normale Supérieure, Paris, France).

The antibodies were isolated from the serum with a Protein A-Sepharose CL-4B column equilibrated with PBS. In order to be used as secondary antibody, antiHomarus $\mathrm{CHH}$ and anti-Homarus GIH were labelled with biotin using a biotinylation kit (Sigma).

The ELISA was carried out as follows. After pretreatment with $1 \%$ glutaraldehyde, microtitre plates (Nunc, Roskilde, Denmark) were coated for $16 \mathrm{~h}$ at $4{ }^{\circ} \mathrm{C}$ with $100 \mu \mathrm{l}$ anti-Astacus $\mathrm{CHH} \operatorname{IgG}(20 \mu \mathrm{g} / \mathrm{ml}$ in $0 \cdot 1 \mathrm{M}$ sodium phosphate buffer, $\mathrm{pH} 8.0$ ) for the quantification of $\mathrm{CHH}$ or with $100 \mu \mathrm{l}$ anti-Homarus $\mathrm{GIH}(20 \mu \mathrm{g} / \mathrm{ml}$ in $0 \cdot 1 \mathrm{M}$ sodium phosphate buffer, $\mathrm{pH} 8 \cdot 0$ ) for the determination of GIH. After being coated with the primary antibody, the wells were washed five times with $0 \cdot 1 \mathrm{M}$ sodium phosphate buffer, $\mathrm{pH} 8 \cdot 0$, and succesively blocked with $400 \mu \mathrm{l}$ $2 \%$ BSA in PBS, $\mathrm{pH} 7 \cdot 2$, for $8 \mathrm{~h}$ at $4{ }^{\circ} \mathrm{C}$. After being blocked, the plates were incubated with $100 \mu \mathrm{l}$ of each collected haemolymph sample for $16 \mathrm{~h}$ at $4{ }^{\circ} \mathrm{C}$ and washed seven times with $400 \mu \mathrm{l} 0 \cdot 1 \%$ Tween 20 in PBS (PBS-T). After addition of the respective biotinylated secondary antibody (anti-Homarus $\mathrm{CHH}$ for $\mathrm{CHH}$ and anti-Homarus GIH for GIH detection, both $5 \mu \mathrm{g} / \mathrm{ml}$ in PBS containing $2 \%$ BSA), the plates were incubated for $6 \mathrm{~h}$ at $37^{\circ} \mathrm{C}$ and washed seven times with PBS-T. Finally, $100 \mu \mathrm{l}$ streptavidin-peroxidase conjugate (1:5 dilution; Histomark $\mathrm{KPL}$ ) was added and the sample was incubated for $1 \mathrm{~h}$ at $37^{\circ} \mathrm{C}$ and washed seven times with $400 \mu \mathrm{PBS}-\mathrm{T}$. The enzymic reaction was then initiated by the addition of $200 \mu \mathrm{l}$ 1,2-benzenediamine $(1 \mathrm{mg} / \mathrm{ml} 0 \cdot 1 \mathrm{M}$ MacIlvaine 
Table 1 Specificity and cross-reactivity of secondary antibodies

\section{Anti-Homarus GIH}

$\mathrm{CHH}-\mathrm{A}$ isoforms $\mathrm{CHH}-\mathrm{B}$ isoforms GlH isoforms

C. maenas hemolymph

\begin{tabular}{ll} 
& + \\
\pm & + \\
+ & - \\
- & - \\
\hline
\end{tabular}

buffer, $\mathrm{pH} 5 \cdot 2$, containing $0 \cdot 8 \mu \mathrm{l} / \mathrm{ml} 40 \% \mathrm{H}_{2} \mathrm{O}_{2}$ ) and stopped by addition of $100 \mu \mathrm{l} 4 \mathrm{~N} \mathrm{H}_{2} \mathrm{SO}_{4}$. The optical density was measured at $492 \mathrm{~nm}$ with an EAR-400 ELISA reader.

Specificity and cross-reactivity of the antibodies To determine the specificity and cross-reactivity of the antibodies in the double-sandwich ELISA, HPLC-purified lobster $\mathrm{GIH}$ and $\mathrm{CHH}$ isoforms were used as antigens. Furthermore, to eliminate possible cross-reactions with crustacean haemolymph proteins, Carcinus maenas haemolymph samples were tested in the ELISA as well. Selection of crab haemolymph was based on an introductory immunochemical study (P V de Kleijn, K P C Janssen, S L Waddy, R Hegeman, W Y Lai, G J Martens \& F Van Herp, unpublished observations), which evaluated the utility of antibodies to detect $\mathrm{GIH}$ and $\mathrm{CHH}$ in sinus gland material of crustaceans other than lobster. No immunoreactivity with crab samples was found, indicating that $\mathrm{CHH}$ and putative GIH from crab is not immunologically related to lobster $\mathrm{CHH}$ and $\mathrm{GIH}$. Therefore possible positive immunoreactions in the cross-reativity assay due to the presence of $\mathrm{CHH}$ and $\mathrm{GIH}$ in the blood samples could be excluded. The specificity and cross-reactivity of the Homarus antisera are summarized in Table 1.

These data are in agreement with the results of Meusy \& Soyez (1991), who show that anti-Homarus $\mathrm{CHH}$ recognizes both lobster $\mathrm{CHH}-\mathrm{A}$ and $-\mathrm{B}$ isoforms and that anti-Homarus GIH also has a low immunoreactivity with both $\mathrm{CHH}$ isoforms. With this knowledge in mind, the ELISAs were carried out to obtain an impression of the relative variations in the total $\mathrm{CHH}$ and GIH in the haemolymph samples.

\section{Results}

\section{Experimental set up}

Female lobsters, in different stages of ovary development, were obtained by inducing the reproduction cycle in 70 animals. These animals were divided into ten groups and at each time point seven animals were killed. To exclude the influence of diurnal rhythms, haemolymph samples of individual animals were taken at the same time of the day. The eyestalks were then ablated for extirpation of the
$\mathrm{X}$-organ and the sinus gland. Finally the ovaries were dissected and their exact developmental stage was determined using weight, colour and ovary factor (Aiken \& Waddy 1980) as parameters.

The first samples were taken just before the experimental animals were placed in the environmental conditions designed to induce reproduction, 28 days before spawning. The other time points for sampling were 16 days, 7 days and 1 day before spawning, and 1 day, 3 days, 10 days, 21 days, 31 days and 40 days after spawning. The various time points were selected to represent characteristic physiological stages in the female reproductive cycle: three stages of immature ovaria (1, 3 and 10 days after spawning), three stages of previtellogenesis $(21,31$ and 40 days after spawning), three stages of vitellogenesis (28, 16 and 7 days before spawning) and one mature stage (1 day before spawning).

This approach made it possible to interpret the individual variations of the data and to evaluate them statistically (Student's $t$-test) according to the different reproductive stages.

\section{Expression, storage and release of $\mathrm{CHH}$ during the reproductive cycle (Fig. 1)}

Figure 1 shows that the expression of $\mathrm{CHH}-\mathrm{A}$ mRNA changes during the different stages of the reproductive cycle. In particular, the increase in mRNA during previtellogenesis is marked and significantly different from the levels measured for the other stages. This increase in mRNA levels is also reflected by the higher amount of $\mathrm{CHH}-\mathrm{A}$ peptide stored in the sinus gland. For all stages, no differences were found between the amounts of $\left[\mathrm{L}-\mathrm{Phe}^{3}\right]-$ and $\left[\mathrm{D}-\mathrm{Phe}{ }^{3}\right]-\mathrm{CHH}-\mathrm{A}$ (results not shown).

For CHH-B, a significant increase in $\mathrm{CHH}-\mathrm{B}$ mRNA levels was found in the previtellogenesis and mature stages when compared with the level in the immature stage. A significant increase in the storage level of $\mathrm{CHH}-\mathrm{B}$ was found during previtellogenesis. As for the $\mathrm{CHH}-\mathrm{A}$ isoforms, no difference was observed between the amounts of neuropeptide isoform $\left[\mathrm{L}-\mathrm{Phe}^{3}\right]-$ and $\left[\mathrm{D}-\mathrm{Phe}^{3}\right]-\mathrm{CHH}-\mathrm{B}$ (results not shown).

In contrast with the mRNA and peptide storage levels, the highest amounts of total $\mathrm{CHH}(\mathrm{CHH}-\mathrm{A}$ and $\mathrm{CHH}-\mathrm{B})$ in the haemolymph were found in the mature stage. They were significantly different from those of the other three stages. Lower increasing levels could be related to the stage of vitellogenesis.

\section{Expression of GIH during the reproductive cycle (Fig. 2)}

Figure 2 shows that the level of GIH mRNA in the immature stage is low and significantly different from the higher levels during previtellogenesis and vitellogenesis. No significant differences were found in the total GIH storage levels in the sinus gland. However, the amount of 


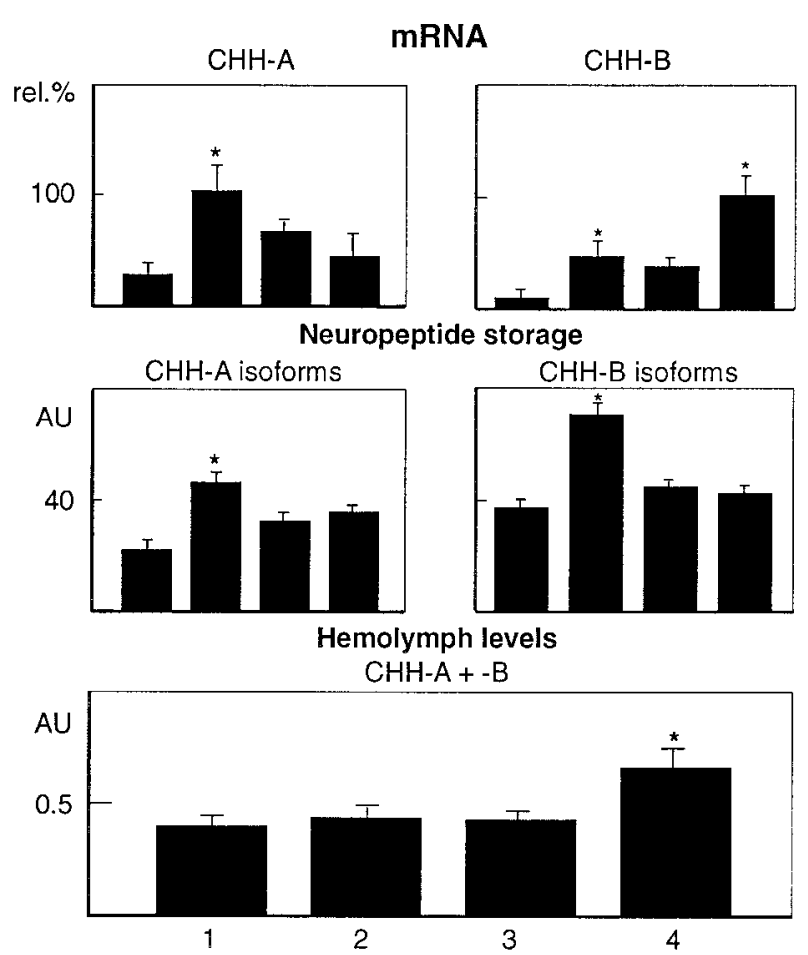

Figure 1 Levels of mRNA expression in the medulla terminalis ganglionaris X-organs, neuropeptide storage in the sinus glands, and haemolymph levels of $\mathrm{CHH}-\mathrm{A}$ and $\mathrm{CHH}-\mathrm{B}$ during the reproductive cycle of female American lobsters. Levels of mRNA are in percentages of the maximum value. Total storage of the $\mathrm{CHH}-\mathrm{A}$ and $\mathrm{CHH}-\mathrm{B}$ isoforms and total $\mathrm{CHH}$ haemolymph levels are in arbitrary units (AU). * indicates a significant difference of: $P<0.02$ between $\mathrm{CHH}-\mathrm{A}$ mRNA levels in the previtellogenic stage and the immature and vitellogenic stages; $P<0.001$ between $\mathrm{CHH}-\mathrm{A}$ neuropeptide levels in the previtellogenic stages and the other three stages. For $\mathrm{CHH}-\mathrm{B}$, * indicates a significant difference of: $P<0.02$ between its mRNA levels in the previtellogenic and mature stages and the immature and vitellogenic stages; $P<0.001$ between $\mathrm{CHH}-\mathrm{B}$ neuropeptide levels in the previtellogenic stages and the other three stages. The significance between total $\mathrm{CHH}$ haemolymph levels $(\mathrm{CHH}-\mathrm{A}+\mathrm{CHH}-\mathrm{B})$ in the mature stage and the three other stages is $P<0.005$. $1=$ immature; $2=$ previtellogenesis; $3=$ vitellogenesis; $4=$ mature.

the GIH I isoform changed dramatically in the immature stage (results not shown). During vitellogenesis, the total GIH level in the haemolymph was significantly lower than in the other stages.

\section{Discussion}

This study reveals that the changes in the levels of $\mathrm{CHH}-\mathrm{A}$ and $-\mathrm{B}$ mRNAs and their respective amounts of stored peptide during the previtellogenic stage are not related to changes in the level of total $\mathrm{CHH}$ in the haemolymph. This finding indicates that there is no relation between intracellular mRNA and peptide levels and the release of the $\mathrm{CHH}$ peptides in the haemolymph at that stage.

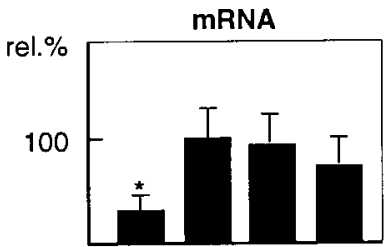

Neuropeptide storage

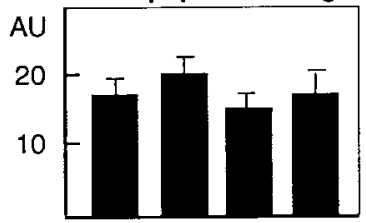

Hemolymph levels

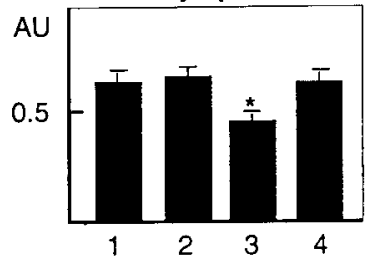

Figure 2 Levels of mRNA expression in the medulla terminalis ganglionaris X-organs, neuropeptide storage in the sinus glands, and haemolymph levels of $\mathrm{GIH}$ during the reproductive cycle of female American lobsters. Levels of mRNA are in percentages of the maximum value. Total neuropeptide storage of the two GIH isoforms and haemolymph levels are in arbitrary units (AU).

* indicates a significant difference between GIH mRNA levels in the immature stage and the pre- and vitellogenic stages $(P<0 \cdot 02)$, and between GIH haemolymph levels in the vitellogenic stage and the three other stages $(P<0 \cdot 001) .1=$ immature;

$2=$ previtellogenesis; $3=$ vitellogenesis; $4=$ mature.

Whereas CHH-B mRNA and total haemolymph $\mathrm{CHH}$ peptide are increased in the mature stage, no differences are found in peptide storage, illustrating that synthesis and release are not related to storage level. This may be because the sinus gland can store large amounts of peptides and that only a small portion is released, as postulated by Stuenkel (1983). The increased CHH-B mRNA levels and the elevated total $\mathrm{CHH}$ haemolymph levels during the mature stage may suggest that $\mathrm{CHH}-\mathrm{B}$ in particular is involved in oocyte maturation. The higher $\mathrm{CHH}-\mathrm{A}$ and -B neuropeptide storage levels in the sinus gland during previtellogenesis than during vitellogenesis was not reflected in the total $\mathrm{CHH}$ content of the haemolymph and may therefore indicate that the peptides are released during late previtellogenesis or at the onset of vitellogenesis. Such a higher release of $\mathrm{CHH}-\mathrm{A}$ and $-\mathrm{B}$ would trigger vitellogenesis during autumn and would be in agreement with the hypothesis of Waddy \& Aiken (1992) that, before winter, females only rarely respond to environmental changes. However, in early November, most females respond to artificially changed day length and temperature by spawning 3 months later. In this respect, an experiment in which more precise time points are taken would give more conclusive results. 


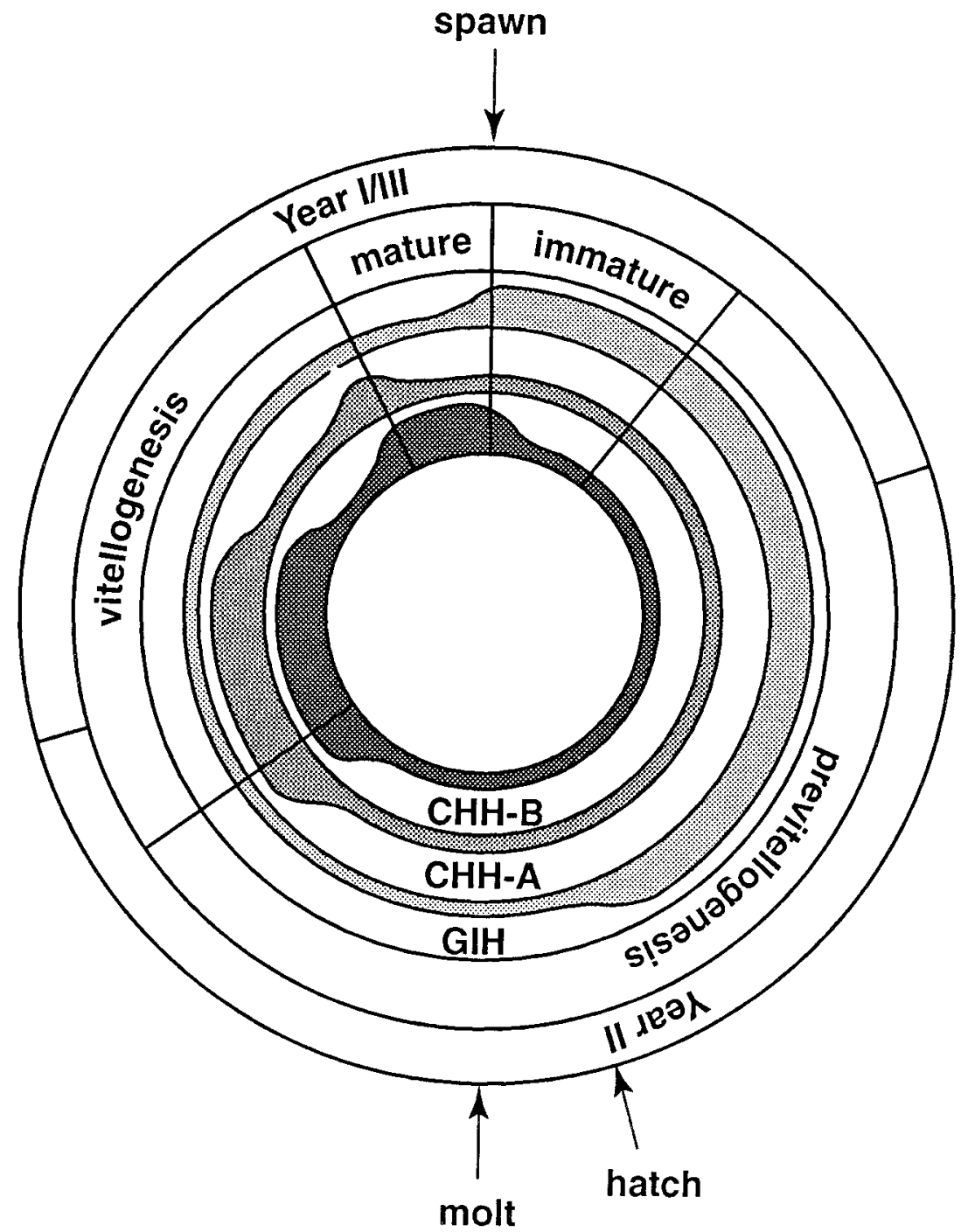

Figure 3 Diagram showing the expected $\mathrm{CHH}-\mathrm{A}, \mathrm{CHH}-\mathrm{B}$ and $\mathrm{GlH}$ haemolymph levels during the biannual reproductive cycle in female lobsters Homarus americanus according to all our results and their interpretation. A new cycle starts when the female has spawned and incubates her eggs of the last cycle. Reading inward from the periphery, the diagram shows: the biannual cycle (outer circle) in which spawning, hatching of the 'last cycle' larvae and the consecutive molt of the adult animal are indicated by arrows; the developmental stages of the ovary (second circle); the variations in respectively the $\mathrm{GIH}$, $\mathrm{CHH}-\mathrm{A}$ and $\mathrm{CHH}-\mathrm{B}$ titres in the haemolymph (inner circles).

To exclude the possibility that our data are due to circadian rhythmicity in the release of the neuropeptides during the reproductive cycle, total $\mathrm{CHH}, \mathrm{GIH}$ and glucose levels were measured in a $24 \mathrm{~h}$ pilot experiment with sampling intervals of $2 \mathrm{~h}$. No differences were found, indicating that there was no circadian rhythm in the release of the hormones (data not shown).

The higher haemolymph levels of GIH at the immature and previtellogenic stages are in agreement with the proposed inhibitory function of this peptide. These higher levels may inhibit the onset of vitellogenesis, while its higher level at maturation may reflect the restart of inhibition after vitellogenesis. However, as the GIH levels are mostly high when $\mathrm{CHH}$ levels decrease, we cannot exclude the possibility that these large amounts of GIH at maturation are due to cross-reactivity with $\mathrm{CHH}$ in the ELISA (see Table 1 and Meusy \& Soyez 1991).

The results of our study did not allow us to unravel some aspects of the intracellular regulation of biosynthesis of the different neuropeptides in the same neuroendocrine cell. 
For this purpose, the use of combined in situ hybridization and immunocytochemical studies, as described by De Kleijn et al. (1992), during a reproductive cycle may be more powerful.

Finally, when the presumed molt-inhibiting function of GIH (De Kleijn et al. 1994) and the reported MIH effects of the hyperglycaemic hormone (Chang et al. 1991) are taken into account, the lower blood levels of both peptides at late previtellogenesis may be responsible for induction of the molting process. Such a combined effect would be ideal for synchronization of the molt and reproductive cycles because molting is then inhibited in the immature ovary stages by GIH and in mature stages by the CHHs.

All the aforementioned interpretations of our results are visualized in Fig. 3. It illustrates the changes in haemolymph levels of $\mathrm{CHH}-\mathrm{A}, \mathrm{CHH}-\mathrm{B}$ and GIH during a molt/reproductive cycle as we expect them based on all our results. High levels of $\mathrm{CHH}-\mathrm{A}$ and $-\mathrm{B}$ after molting and at the onset of vitellogenesis are followed by a lower $\mathrm{CHH}$ level in winter after which the $\mathrm{CHH}-\mathrm{B}$ level in particular increases during the last stages of vitellogenesis. The haemolymph level of GIH is mostly high when $\mathrm{CHH}$ is low and vice versa. Levels increase after spawning and remain high until they decrease before molting, possibly during hatching of the larvae.

In conclusion, the variations in $\mathrm{CHH}$ and $\mathrm{GIH}$ activity during the reproductive and molting cycle of the lobster suggest that both are involved in the synchronization of these two cycles. Both biological cycles are controlled by the interaction of several neuropeptides, juvenoids and steroids, as recently reviewed by Chang (1997), Charmantier et al. (1997) and Van Herp \& Soyez (1997). Therefore monitoring of complete cycles by using specific antisera against the different forms of the $\mathrm{CHH}$ and GIH neuropeptides should be useful in determining the precise roles of $\mathrm{CHHs}$ and $\mathrm{GIH}$ in these cycles.

\section{Acknowledgements}

We thank Dr Daniel Soyez for providing the antibodies, and Dr Jorg Klein and Dr Heiner Dircksen for instruction in the setting up of the ELISA method. We are grateful to The Netherlands Organization for Scientific Research (NWO), The Royal Dutch Academy of Sciences (KNAW) and the University of Nijmegen for financial support to allow D De $\mathrm{K}$ to visit Canada.

\section{References}

Aiken DE \& Waddy SL 1980 Reproductive Biology. In The Biology and Management of Lobsters, Vol I Physiology and Behavior, pp 215-276. Eds JS Cobb \& BF Phillips. New York: Academic Press. Chang ES 1997 Chemistry of crustacean hormones that regulate growth and reproduction. In Recent Advances In Marine Biotechnology, pp 163-178. Eds M Fingerman, R Nagabhushanan \& MF Thompson. New Dehli: Oxford and IBH Publishing Co.
Chang ES, Prestwich GD \& Bruce MJ 1991 Amino acid sequence of a peptide with both molt-inhibiting and hyperglycemic activities in the lobster, Homarus americanus. Biochemical and Biophysical Research Communications 171 818-826.

Charmantier G, Charmantier-Daures M \& Van Herp 1997 Hormonal regulation of growth and reproduction in crustaceans. In Recent Advances In Marine Biotechnology, pp 109-161. Eds M Fingerman, R Nagabhushanan \& MF Thompson. New Dehli: Oxford and IBH Publishing Co.

Chomzcynski P \& Sacchi N 1987 Single-step method of RNA isolation by acid guanidinium thiocyanate-phenol-chloroform extraction. Analytical Biochemistry 162 156-159.

De Kleijn DPV, Coenen T, Laverdure AM, Tensen CP \& Van Herp F 1992 Localization of mRNAs encoding the Crustacean Hyperglycemic Hormone $(\mathrm{CHH})$ and Gonad Inhibiting Hormone $(\mathrm{GIH})$ in the X-organ sinus gland complex of the lobster Homarus americanus. Neuroscience $\mathbf{5 1} 121-128$.

De Kleijn DPV, Sleutels FJGT, Martens GJM \& Van Herp F 1994 Cloning and expression of mRNA encoding prepro Gonad Inhibiting Hormone $(\mathrm{GIH})$ in the lobster Homarus americanus. FEBS Letters 353 255-258.

De Kleijn DPV, De Leeuw EPH, Van Den Berg MC, Martens GJM \& Van Herp F 1995 Cloning and expression of two mRNAs encoding structurally different crustacean hyperglycemic hormone precursors in the lobster Homarus americanus. Biochimica et Biophysica Acta 1260 62-66.

Gomez R \& Nayar KK 1965 Certain endocrine influences in the reproduction of the crab Parathelphusa hydrodromous. Zoologisches Jahrbuch, Abteilung Allgemeine Zoologie und Physiologie der Tiere 71 694-701.

Gorgels-Kallen JL \& Van Herp F 1981 Localization of the crustacean hyperglycemic hormone $(\mathrm{CHH})$ in the $\mathrm{X}$-organ sinus gland complex in the eyestalk of the crayfish Astacus leptodactylus (Nordmann 1842). Journal of Morphology 50 347-355.

Kallen JL \& Meusy JJ 1989 Do the neurohormones VIH (vitellogenesis inhibiting hormone) and $\mathrm{CHH}$ (crustacean hyperglycemic hormone) of crustaceans have a common precursor? Immunolocalization of $\mathrm{VIH}$ and $\mathrm{CHH}$ in the $\mathrm{X}$-organ sinus gland complex of the lobster Homarus americanus. Invertebrate Reproduction and Development 16 43-53.

Keller R 1992 Crustacean neuropeptides: structures, functions and comparative aspects. Experientia 48 439-448.

Klein JM 1989 Diplomarbeit. Bonn: Institut fur Zoophysiologie.

Meusy J-J \& Soyez D 1991 Immunological relationships between neuropeptides from the sinus gland of the lobster Homarus americanus, with special references to the vitellogenesis inhibiting hormone and crustacean hyperglycemic hormone. General and Comparative Endocrinology 81 410-418.

Otsu T 1963 Bihormonal control of sexual cycle in the freshwater crab Potamon dehaani. Embryologica 8 1-20.

Soyez D, Van Deijnen J-E \& Martin M 1987 Isolation and characterization of a vitellogenesis inhibiting factor from sinus glands of the lobster Homarus americanus. Jounal of Experimental Zoology 244 479-484.

Soyez D, Le Caer JP, Noel PY \& Rosier J 1991 Primary structure of two isoforms of the vitellogenesis inhibiting hormone from the lobster Homarus americanus. Neuropeptides 20 25-32.

Soyez D, Van Herp F, Rossier J, Le Caer JP, Tensen CP \& Lafont R 1994 Evidence for a conformational polymorphism of invertebrate neurohormones. Journal of Biological Chemistry 269 18295-18298.

Stuenkel EL 1983 Biosynthesis and axonal transport of proteins and identified peptide hormones in the $\mathrm{X}$-organ sinus gland neurosecretory system. Journal of Comparative Physiology 153 191-205.

Tensen CP, Janssen KPC \& Van Herp F 1989 Isolation, characterization and physiological specificity of the crustacean hyperglycemic factors from the sinus gland of the lobster Homarus americanus (Milne-Edwards). Invertebrate Reproduction and Development 16 155-164. 
Tensen CP, De Kleijn DPV \& Van Herp F 1991 Cloning and sequence analysis of cDNAs encoding two crustacean hyperglycemic hormones in the lobster Homarus americanus. European Journal of Biochemistry 200 103-106.

Van Herp F 1992 Inhibition and stimulating neuropeptides controlling reproduction in Crustacea. Invertebrate Reproduction and Development 22 21-30.

Van Herp F \& Soyez D 1997 Reproductive biology in invertebrates: Arthropoda-Crustacea. In Progress In Reproductive Endocrinology,
Part A, vol 10. Ed TS Adams. New Dehli: Oxford and IBH Publishing Co. (In Press).

Waddy SL \& Aiken DE 1992 Environmental intervention in the reproductive process of the American lobster, Homarus americanus. Invertebrate Reproduction and Development 22 245-252.

Received 21 April 1997

Accepted 1 September 1997 